\title{
FAKTOR-FAKTOR YANG MEMPENGARUHI KEPUTUSAN ORANG TUA DALAM MEMILIH LEMBAGA PENDIDIKAN (STUDI EMPIRIS PADA SMA IMTEK PAGEDANGAN TANGERANG)
}

\author{
Riri Oktarini ${ }^{1}$ \\ Dosen Prodi D-III Sekretari Universitas Pamulang \\ dosen02443@unpam.ac.id \\ Rahmayanti $^{2}$ \\ Dosen Prodi D-III Sekretari Universitas Pamulang \\ rahmayanti.dosen@gmail.com
}

\begin{abstract}
ABSTRAK-Tujuan diadakannya penelitian adalah mengetahui pengaruh lokasi, harga, dan promosi terhadap keputusan orang tua dalam memilih lembaga pendidikan pada SMA IMTEK Pagedangan Tangerang. Metode penelitian dengan metode Asosiatif. Sampel digunakan sebanyak 87. Teknik analisis data dengan regresi linier berganda. Hasil penelitian menunjukan bahwa : 1). Semakin baik tingkat lokasi dari suatu sekolah maka akan membuat peningkatan keputusan orang tua dalam memilih lembaga pendidikan pada SMA IMTEK Pagedangan Tangerang terbukti dari probabilitas parsial $(0,008<0,05)$. 2). Semakin mahal harga yang ditawarkan oleh pihak sekolah maka akan membuat penurunan keputusan orang tua dalam memilih lembaga pendidikan pada SMA IMTEK Pagedangan Tangerang terbukti dari probabilitas parsial $(0,000<0,05)$. 3). Semakin baik promosi yang dilakukan oleh pihak sekolah dan semakin gencar maka akan membuat peningkatan keputusan orang tua dalam memilih lembaga pendidikan pada SMA IMTEK Pagedangan Tangerang terbukti dari probabilitas parsial $(0,000<0,05)$. 4). Semakin baik tingkat lokasi dari suatu sekolah, semakin baik penetapan harga, dan semakin gencar promosi bila dipadukan secara serempak maka akan membuat peningkatan keputusan orang tua dalam memilih lembaga pendidikan pada SMA IMTEK Pagedangan Tangerang terbukti dari probabilitas simultan $(0,000<0,05)$.
\end{abstract}

\section{Kata Kunci: Lokasi, Harga, Promosi, Keputusan Orang Tua}

ABSTRACT-The purpose of the research was to determine the effect of location, price, and promotion on parents' decisions in choosing educational institutions at SMA IMTEK Pagedangan Tangerang. The research method is the associative method. The sample used was 87. The data analysis technique was multiple linear regression. The results showed that: 1). The better the location level of a school will make an increase in the decision of parents in choosing an educational institution at SMA IMTEK Pagedangan Tangerang as evidenced by a partial probability $(0.008<0.05)$. 2). The more expensive the price offered by the school will make a decrease in the decision of parents in choosing an educational institution at SMA IMTEK Pagedangan Tangerang as evidenced by a partial probability $(0.000<0.05)$. 3). The better the promotion carried out by the school and the more intense it will make an increase in the decision of parents in choosing educational institutions at SMA IMTEK Pagedangan Tangerang as evidenced by partial probability $(0.000<0.05) .4)$. The better the location level of a school, the better the pricing, and the more incessant promotion when combined simultaneously it will make an increase in parents' decisions in choosing educational 
institutions at SMA IMTEK Pagedangan Tangerang as evidenced by the simultaneous probability $(0.000<0.05)$.

Keywords: Location, Price, Promotion, Parents' Decision

\section{PENDAHULUAN}

\section{Latar Belakang}

Persaingan dalam industri jasa pendidikan setiap tahun mengalami peningkatan persaingan yang cukup ketat, dengan adanya persaingan yang ketat ini membuat pihak lembaga pendidikan mau tidak mau harus mengeluarkan segenap daya dan tenaga untuk membuat calon siswa menjadi tertarik untuk mau bersekolah di lembaga pendidikan tersebut. Salah satu lembaga pendidikan yang saat ini sedang mengalami permasalahan mengenai tingkat jumlah siswa yang menurun adalah SMA IMTEK Pagedangan Tangerang seperti yang dilihat dari tabel berikut:

Tabel 1. Jumlah Siswa SMA Imtek Pagedangan Tangerang
\begin{tabular}{|c|c|c|c|c|}
\hline Tahun & $\begin{array}{c}\text { Jumlah Siswa } \\
\text { Awal Tahun }\end{array}$ & $\begin{array}{c}\text { Jumlah Siswa } \\
\text { Masuk/Baru }\end{array}$ & $\begin{array}{c}\text { Jumlah Siswa } \\
\text { Akhir Tahun }\end{array}$ & $\%$ \\
\hline $2016 / 2017$ & 450 & 85 & 535 & $118,89 \%$ \\
\hline $2017 / 2018$ & 535 & 79 & 614 & $114,77 \%$ \\
\hline $2018 / 2019$ & 614 & 76 & 690 & $112,38 \%$ \\
\hline
\end{tabular}
Sumber: SMA IMTEK Pagedangan Tangerang (2020)

Dari tabel 1 terlihat dimana hampir setiap tahun jumlah siswa yang masuk selalu menurun, pada tahun ajaran 2016/2017 jumlah siswa masuk sebanyak 85 siswa, kemudian di tahun ajaran 2017/2018 menurun menjadi 79 siswa, sedangkan memasuki tahun ajaran 2018/2019 jumlah siswa masuk juga mengalami penurunan menjadi 76 siswa. Dari tabel tersebut pihak sekolah harus segera mengevaluasi penyebab kenapa bisa terjadi penurunan yang terus menerus tersebut.

Banyak hal yang menyebabkan mengapa keputusan orang tua dalam memilih lembaga pendidikan pada SMA IMTEK Pagedangan Tangerang menjadi menurun salah satu indikasinya adalah keadaan dari lokasi yang belum strategis.

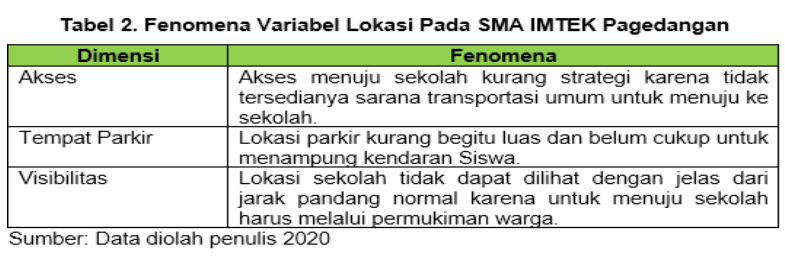

Tabel tersebut menunjukan memang banyak fenomena yang terjadi terkait lokasi pada SMA IMTEK Pagedangan Tangerang dimulai dari akses menuju sekolah, tempat parkir, serta visibilitas yang memang harus segera di perbaiki oleh pihak sekolah agar penurunan jumlah siswa tidak kembali lagi terjadi penurunan.

Tabel 3. Biaya Pendidikan

\begin{tabular}{|c|c|}
\hline Tahun & \multicolumn{2}{|c|}{ Biaya Pendidikan Per Bulan } \\
\hline $2016 / 2017$ & Rp. 120.000 \\
\hline $2017 / 2018$ & Rp. 135.000 \\
\hline $2018 / 2019$ & Rp. 150.000 \\
\hline
\end{tabular}

Sumber: SMA IMTEK Pagedangan Tangerang (2020)

Tabel 3 menunjukan bahwa biaya SPP pada SMA IMTEK Pagedangan Tangerang 
selama tiga tahun terakhir mengalami peningkatan secara signifikan hal tersebut sangat mempengaruhi Keputusan Orang Tua Dalam Memilih SMA IMTEK Pagedangan Tangerang mengingat harga merupakan bagian yang sangat sensitif terlebih bila melihat kemampuan orang tua yang memiliki keadaan finansial pas-pasan.

Faktor selanjutnya adalah promosi yang ditawarkan pihak sekolah belum terlalu gencar. Hasil pengamatan penulis melihat adanya suatu kekurangan dalam menarik minat siswa seperti, belum gencarnya pihak sekolah dalam menginformasikan melalui berbagai macam media. Saat ini pihak sekolah hanya mengandalkan spanduk saja untuk memberikan informasi kepada siswa, padahal bauran promosi tidak mencakup itu saja ada banyak hal promosi yang bisa dilakukan seperti iklan, brosur, potongan harga serta memanfaat kecanggihan teknologi seperti internet.

\section{LANDASAN TEORI}

\section{Lokasi}

Menurut Tjiptono (2015:345) "Lokasi mengacu pada berbagai aktivitas pemasaran yang berusaha memperlancar dan mempermudah penyampaian atau penyaluran barang dan jasa dari produsen kepada konsumen". Menurut Lupiyoadi dan Hamdani (2011:92) "lokasi adalah keputusan yang dibuat perusahaan atau instansi pendidikan berkaitan dengan di mana operasi dan stafnya akan ditempatkan”.

\section{Harga}

Menurut Kotler dan Armstrong (2014:151), "harga adalah sejumlah uang yang dibebankan atas suatu barang atau jasa atau jumlah dari nilai uang yang ditukar konsumen atas manfaat-manfaat karena memiliki atau menggunakan produk atau jasa tersebut". Menurut Stanton (2013:174), "harga adalah jumlah uang (kemungkinan ditambah beberapa barang) yang dibutuhkan untuk memperoleh beberapa kombinasi sebuah produk dan pelayanan yang menyertainya".

\section{Promosi}

Menurut Kotler dan Armstrong (2014:76), "Promosi mengacu pada kegiatan atau berkomunikasi dua Merek produk dan membujuk pelanggan sasaran untuk pembeli”. Menurut Stanton (2013:126), "promosi adalah unsur dalam bauran pemasaran perusahaan yang di daya gunakan untuk memberitahukan, membujuk, dan mengingatkan tentang produk perusahaan". Menurut Lupiyoadi (2013:92) "Promosi adalah kegiatan yang dilakukan perusahaan untuk mengkomunikasikan manfaat produk dan sebagai alat untuk mempengaruhi 
konsumen dalam kegiatan pembelian atau penggunaan jasa sesuai dengan kebutuhan”.

\section{Keputusan Pembelian}

Menurut Kotler dan Amstrong (2014:251-252), “keputusan pembelian adalah suatu proses penyelesaian masalah yang terdiri dari menganalisa atau pengenalan kebutuhan dan keinginan, pencarian informasi, penilaian sumbersumber seleksi terhadap alternatif pembelian, keputusan pembelian, dan perilaku setelah pembelian”. Schiffman \& Kanuk (2013:549), "secara umum keputusan pembelian adalah seleksi dari dua atau lebih pilihan alternative".

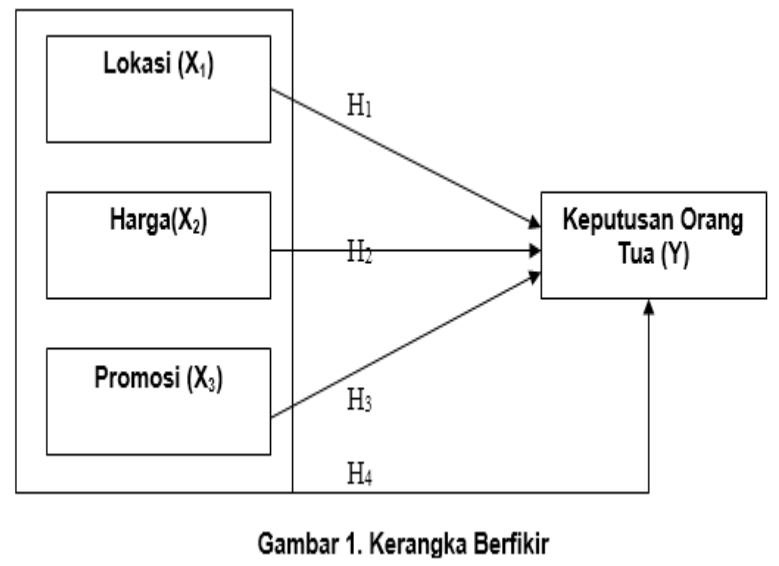

\section{METODOLOGI PENELITIAN}

Metode Asosiatif adalah metode penelitian ini. Sugiyono (2015:44) "penelitian Asosiatif bertujuan untuk mengetahui pengaruh atau hubungan antara dua variabel lebih". Populasi seluruh wali murid pada SMA IMTEK Pagedangan Tangerang berjumlah 690 wali murid, sedangkan sampel sebanyak 87 responden. Teknik analisis data dengan Regresi Linier Berganda.

\section{HASIL DAN PEMBAHASAN}

\section{Uji Validitas}

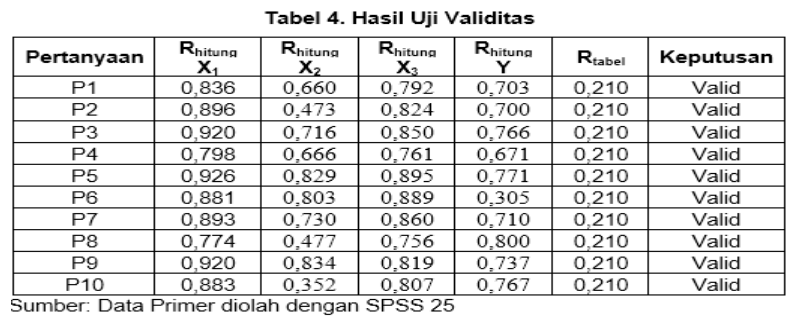

Dari 40 pernyataan disebar kepada seluruh wali murid terlihat bahwa seluruhnya memiliki angka $r_{\text {-hitung }}>r_{\text {-tabel }}(0,210)$ dengan semua item pernyataan valid.

\section{Uji Reliabilitas}

Tabel 5. Hasil Uji Reliabilitas
\begin{tabular}{|c|c|c|}
\hline Variabel & Cronbach Alpha & Keputusan \\
\hline Lokasi $\left(\mathrm{X}_{1}\right)$ & 0,965 & Sangat Reliabel \\
\hline Harga $\left(\mathrm{X}_{2}\right)$ & 0,856 & Sangat Reliabel \\
\hline Promosi $\left(\mathrm{X}_{3}\right)$ & 0,948 & Sangat Reliabel \\
\hline Keputusan Pembelian $(\mathrm{Y})$ & 0,880 & Sangat Reliabel \\
\hline
\end{tabular}
Sumber: Hasil Olahan Data SPSS 25

Tabel 5 diatas menunjukan kriteria reliabel sudah terpenuhi sempurna dengan alpha cronbach diatas nilai kritis.

\section{UJI Asumsi Klasik}

\section{Uji Normalitas}




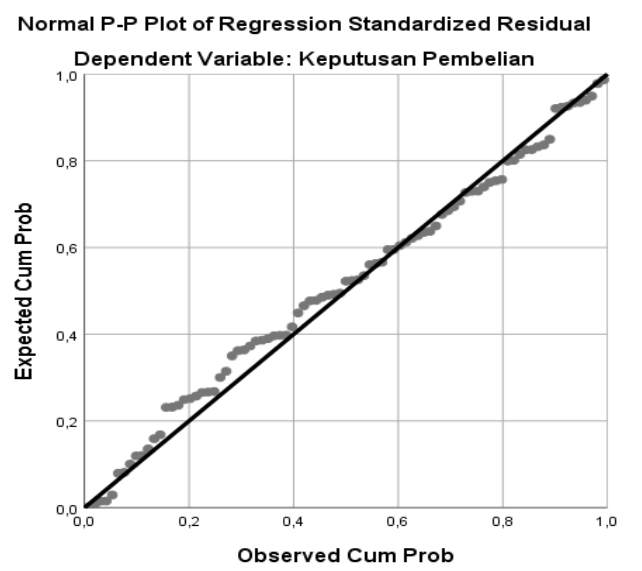

Gambar 2. Uji Normalitas Data P-P Plot

Penyebaran garis terlihat pada Gambar

2 sudah mengikuti garis diagonal dan tidak ada yang melebar jauh, yang merupakan asumsi normalitas sudah dapat dipenuhi.

\section{Uji Multikolineritas}

Tabel 6. Uji Multikolinearitas

\begin{tabular}{|l|c|c|}
\hline \multirow{2}{*}{ Model } & \multicolumn{2}{|c|}{ Collinearity Statistics } \\
\cline { 2 - 3 } & Tolerance & VIF \\
\hline Lokasi & 0,668 & 1,498 \\
\hline Harga & 0,892 & 1,121 \\
\hline Promosi & 0,612 & 1,634 \\
\hline
\end{tabular}

a. Dependent Variable: Keputusan Pembelian Sumber: Hasil Olahan Data SPSS 25

Pada tabel 6 menunjukan tidak terdapat adanya suatu gejala-gejala yang memungkinkan adanya multikolineritas karena $\mathrm{VIF}<10$ dan toleransinya $>0,10$.

\section{Uji Heteroskedastisitas}

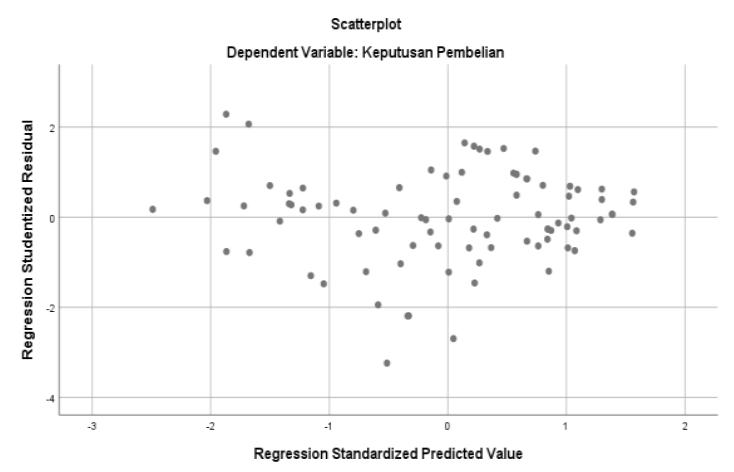

Gambar 3 Pengujian Heteroskedastisitas Dengan Grafik
Penyebaran data terlihat menyebar secara acak dari bawah maupun dari atas dan tidak ada yang membentuk pola, sehingga data peneitian tidak terjadi heteroskedastisitas.

\section{Regresi Linier Berganda}

\begin{tabular}{|c|c|c|c|c|c|c|}
\hline & \multirow[t]{2}{*}{ Model } & \multicolumn{2}{|c|}{$\begin{array}{l}\text { Unstandardized } \\
\text { Coefficients }\end{array}$} & \multirow{2}{*}{$\begin{array}{c}\begin{array}{c}\text { Standardize } \\
d \\
\text { Coefficients }\end{array} \\
\text { Beta } \\
\end{array}$} & \multirow[t]{2}{*}{$\mathrm{t}$} & \multirow[t]{2}{*}{ Sig. } \\
\hline & & B & Std. Error & & & \\
\hline \multirow[t]{4}{*}{1 . } & (Constant) & 42,107 & 3,552 & & 11,853 & 0,000 \\
\hline & Lokasi & 0,130 & 0,048 & 0,244 & 2,701 & 0,008 \\
\hline & Harga & $-0,426$ & 0,085 & $-0,392$ & $-5,017$ & 0,000 \\
\hline & Promosi & 0,173 & 0,047 & 0,346 & 3,667 & 0,000 \\
\hline
\end{tabular}

$\mathrm{Y}=42,107+0,130 \mathrm{X}_{1}-\mathbf{0}, \mathbf{4 2 6} \mathrm{X}_{2}+0.173 \mathrm{X}_{3}$

1. Nilai constant 42,107 artinya apabila seluruh tiga variabel tidak mengalami peningkatan sama sekali, maka keputusan pembelian tetap 42,107 .

2. Lokasi memperoleh nilai regresi $0,130 \mathrm{X}_{1}$ berarti bahwa pengaruh yang searah yang artinya semakin baik tingkat lokasi dari suatu sekolah maka akan membuat peningkatan keputusan pembelian 0,130.

3. Harga memperoleh nilai regresi $-0,426 \mathrm{X}_{2}$ berarti bahwa pengaruh yang tidak searah yang artinya semakin mahal harga yang ditawarkan maka akan membuat penurunan keputusan pembelian -0,426.

4. Promosi memperoleh nilai regresi $0,173 X_{3}$ berarti bahwa pengaruh yang searah yang artinya semakin baik promosi yang dilakukan dan semakin gencar maka akan membuat peningkatan keputusan pembelian 0,173 . 


\section{Koefisien Determinasi}

Tabel 8. Koefisien Determinasi
\begin{tabular}{|l|r|r|c|c}
\hline Model & R & R Square & $\begin{array}{c}\text { Adjusted R } \\
\text { Square }\end{array}$ & $\begin{array}{c}\text { Std. Error of the } \\
\text { Estimate }\end{array}$ \\
\hline 1 &, $741^{\text {a }}$ & 0,549 & 0,532 & $4,3971$. \\
\hline
\end{tabular}
a. Predictors: (Constant), Promosi, Harga, Lokasi
b. Dependent Variable: Keputusan Pembelian
Sumber: Hasil Olahan Data SPSS 25

Rsquare dari 0,549 atau juga 54,9\% adalah kontribusi dari 3 variabel bebas terhadap keputusan pembelian, sedangkan selebihnya $45,1 \%$ diakibatkan adanya konstruk lain yang tidak termasuk kedalam model ini.

\section{Uji t Parsial}

Tabel 9. Uji T Parsial

\begin{tabular}{|c|c|c|c|c|c|c|}
\hline & \multirow[t]{2}{*}{ Model } & \multicolumn{2}{|c|}{$\begin{array}{l}\text { Unstandardized } \\
\text { Coefficients }\end{array}$} & \multirow{2}{*}{$\begin{array}{c}\begin{array}{c}\text { Standardize } \\
\text { d } \\
\text { Coefficients }\end{array} \\
\text { Beta }\end{array}$} & \multirow[t]{2}{*}{$\mathrm{t}$} & \multirow[t]{2}{*}{ Sic } \\
\hline & & $B$ & Std. Error & & & \\
\hline \multirow[t]{4}{*}{1} & (Constant) & 42,107 & 3,552 & & 11,853 & 0,1 \\
\hline & Lokasi & 0,130 & 0,048 & 0,244 & 2,701 & 0,1 \\
\hline & Harga & $-0,426$ & 0,085 & $-0,392$ & $-5,017$ & 0,1 \\
\hline & Promosi & 0,173 & 0,047 & 0,346 & 3,667 & 0,1 \\
\hline
\end{tabular}

1. Hasil pengujian regresi pada tabel 9 probabilitas $(0,008<0,05)$ menunjukan diterimanya $\mathrm{H}_{\mathrm{a} 1}$ dan ditolaknya $\mathrm{H}_{\mathrm{o} 1}$ yang berarti lokasi berpengaruh parsial terhadap keputusan orang tua dalam memilih lembaga pendidikan pada SMA IMTEK Pagedangan Tangerang.

2. Hasil pengujian regresi pada tabel 9 probabilitas $(0,000<0,05)$ menunjukan diterimanya $\mathrm{H}_{\mathrm{a} 2}$ dan ditolaknya $\mathrm{H}_{\mathrm{o} 2}$ yang berarti harga berpengaruh parsial terhadap keputusan orang tua dalam memilih lembaga pendidikan pada SMA IMTEK Pagedangan Tangerang.
3. Hasil pengujian regresi pada tabel 9 probabilitas $(0,000<0,05)$ menunjukan diterimanya $\mathrm{H}_{\mathrm{a} 3}$ dan ditolaknya $\mathrm{H}_{\mathrm{o} 3}$ yang berarti promosi berpengaruh parsial terhadap keputusan orang tua dalam memilih lembaga pendidikan pada SMA IMTEK Pagedangan Tangerang.

\section{Uji F Simultan}

\section{Tabel 10. Uji F hitung}

\begin{tabular}{|l|l|r|r|r|c|c|}
\hline \multicolumn{2}{|c|}{ Model } & Sum of Squares & \multicolumn{1}{c|}{ df } & Mean Square & F & Sig. \\
\hline \multirow{2}{*}{1} & Regression & 1950,815 & 3 & 650,272 & 33,632 &, $000^{b}$ \\
\cline { 2 - 7 } & Residual & 1604,794 & 83 & 19,335 & & \\
\cline { 2 - 8 } & Total & 3555,609 & 86 & & & \\
\hline
\end{tabular}

a. Dependent Variable: Keputusan Pembelian

b. Predictors: (Constant), Promosi, Harga, Lokasi

Sumber: Hasil Olahan Data SPSS 25

Tabel 10 menunjukkan bahwa angka probabilitas lebih kecil dan lebih rendah dari 0,01 atau $(0,000<0,01)$, yang berarti diterimanya $\mathrm{H}_{24}$ dan ditolaknya $\mathrm{H}_{04}$ artinya lokasi, harga, dan promosi mempengaruhi simultan terhadap keputusan orang tua dalam memilih lembaga pendidikan pada SMA IMTEK Pagedangan Tangerang.

\section{PENUTUP}

\section{Kesimpulan}

1. Semakin baik tingkat lokasi dari suatu sekolah maka akan membuat peningkatan keputusan orang tua dalam memilih lembaga pendidikan pada SMA IMTEK Pagedangan Tangerang terbukti dari probabilitas parsial $(0,008<0,05)$. 
2. Semakin mahal harga yang ditawarkan oleh pihak sekolah maka akan membuat penurunan keputusan orang tua dalam memilih lembaga pendidikan pada SMA IMTEK Pagedangan Tangerang terbukti dari probabilitas parsial $(0,000<0,05)$.

3. Semakin baik promosi yang dilakukan oleh pihak sekolah dan semakin gencar maka akan membuat peningkatan keputusan orang tua dalam memilih lembaga pendidikan pada SMA IMTEK Pagedangan Tangerang terbukti dari probabilitas parsial $(0,000<0,05)$.

4. Semakin baik tingkat lokasi dari suatu sekolah, semakin baik penetapan harga, dan semakin gencar promosi bila dipadukan secara serempak maka akan membuat peningkatan keputusan orang tua dalam memilih lembaga pendidikan pada SMA IMTEK Pagedangan Tangerang terbukti dari probabilitas simultan $(0,000<0,05)$.

\section{DAFTAR PUSTAKA}

Kotler, Philip dan Gary, Amstrong, (2014), "Dasar-Dasar Manajemen Pemasaran", Penerbit, Erlangga, Jakarta.

Lupiyoadi, R. (2013), "Manajemen Pemasaran Jasa Berbasis Kompetensi”. (Edisi 3). Salemba Empat, Jakarta.

Lupiyoadi, R., dan Hamdani, A. (2011). "Manajemen Pemasaran Jasa". Edisi. Dua. Salemba Empat.

Oktarini, R. (2019), "Pengaruh Kualitas Pelayanan Dan Harga Terhadap Kepuasan Pelanggan Pengguna Jasa
Aplikasi Gojek Di Kota Tangerang", Jurnal Sekretari, Vol. 6, No. 2.

Oktarini, R. (2020), "Pengaruh Harga dan Citra Merek Terhadap Keputusan Pembelian Handphone Merek Xiaomi di Kota Tangerang”. Jurnal Pemasaran Kompetitif. Vol. 3. No. 3.

Schiffman dan Kanuk, (2013), "Perilaku Konsumen", Edisi ke 7, PT Indeks, Jakarta.

Stanton, William J. (2013). "Prinsip Pemasaran". Jilid Satu. Edisi Kesepuluh. Jakarta: Erlangga.

Solihin, D, (2020), "Faktor-Faktor Yang Mempengaruhi Kinerja Pemasaran Pada PT. Prima Ufuk Semesta (Studi Empiris Pada Outlet Rekanan PT. Prima Ufuk Semesta di Wilayah Jabodetabek)", Jurnal Semarak. Vol. 3 No. 1.

Solihin, D. (2020), "Pengaruh Kepercayaan Pelanggan Dan Promosi Terhadap Keputusan Pembelian Konsumen Pada Online Shop Mikaylaku Dengan Minat Beli Sebagai Variabel Intervening". Jurnal Mandiri. Vol. 4. No. 1.

Solihin, D., dan Wibawanto, E. (2020). "Pengaruh Kualitas Pelayanan, Harga, Dan Promosi Terhadap Keputusan Pelanggan Dalam Memilih Klub Basket Satria Indonesia Tangerang Selatan". Jurnal Pemasaran Kompetitif. Vol. 3. No. 3.

Sugiyono, (2015), "Metode Penelitian Manajemen", CV Alvabeta, Bandung.

Tjiptono, F. (2015), "Strategi Pemasaran", Penerbit Andi, Yogyakarta. 